\title{
A Review on Medicinal uses of Weeds in Sri Lanka
}

\author{
E.R.H.S.S. Ediriweera \\ Department of Nidana Chikithsa (Diagnosis and Treatment), Institute of Indigenous Medicine, \\ University of Colombo, Rajagiriya, Sri Lanka
}

Accepted 30th August 2007

\begin{abstract}
Ayurveda, the 'Science of Life' is a system of treatment for promoting health, prevention and curing of illnesses. In Sri Lanka, Ayurvedic and traditional physicians treat patients successfully using herbs and other natural resources. Some of the herbs used to prepare medicines are considered as weeds by agriculturists. They generally advise farmers to destroy these weeds in order to obtain a better cash-crop harvest, with out realizing the medicinal value and uses of these plants. Though many of the farmers have quite a good knowledge on medicinal value of these herbs, in order to get a good harvest from their cultivation, they generaly destroy these plants. Some of the farmers do not have any knowledge on medicinal value of weeds. Aim of this study is to make the society aware of medicinal values of many weeds which grow naturally, without any effort or outlay of money from the farmers, and to protect and propagate planned cultivation of such weeds. This would make many highly useful medicinal plants freely available to the public while providing a source of an additional income to the farmers. In the long run, with proper planning and support, the growing and marketing of medicinal herbs which are currently categorized as weeds could become a very good source of income to the country, while providing an additional, easily available source of natural medicines to the populace. More over such herbs could be made use to serve as live ground covers in cultivated fields. Possible hazards of herbicides could also be minimized with exploitation of such weeds.
\end{abstract}

Keywords: weeds, medicinal uses

\section{INTRODUCTION}

A weed in a general sense is a plant, usually wild or feral, that is commonly considered to be a nuisance in a garden, lawn, or other agricultural development. More specifically the term is often used to describe plants that grow and reproduce aggressively. Weeds may be unwanted because they are unsightly, or because they limit the growth of other plants by blocking light or using up nutrients from the soil. The term weed in its general sense is a subjective one, without any classification value, since a plant or herb is not a weed when growing where it belongs or is wanted.

Some weeds are called, "beneficial plants or herbs" as they are edible, use for food or herbal medicine. Other advantage of such beneficial herbs may be the keeping away of some insects pests of crops.

The Ayurveda system of medicine was first taught and practiced by the ancient Sages of India over 4000 years ago. It is a highly effective and advanced method of treatment with a deep insight to the root causes of ailments and its value or the effectiveness has not diminished with the time. In fact, more and more people are becoming interested in Ayurveda nowadays, worldwide.

Sri Lankan Traditional Medicinal and Treatment Methods are quite similar to the Ayurvedic methods; but have many Indigenous herbs, compounds and even techniques integrated as well. We believe that these have been developed, practiced and even improvements added on from time to time, since the country was inhabited. The Traditional Physicians of Sri Lanka use a wide variety of herbs to prepare various medicines for different ailments. Some of the valuable medicinal plants used therein are considered as weeds by agriculturists, from their focal point of view. Exploitation of such herbs is also beneficial as they conserve soil by serving as a live ground cover in crop lands. Doing away with chemical weed control also cause to minimize pos- 
sible hazards of herbicides on humans, animals and environments.

\section{OBJECTIVE}

This study was undertaken to make the world understand the value of weeds and to persuade them to protect and propagate the cultivation of weeds with due consideration and proper planning.

\section{Data gathered}

Data submitted here was gathered from local knowledge on Ayurvedic and traditional medicine, research work carried out by the author on Scoparia dulcis, olla leaves and from textbooks. According to this study, some of the weeds are used singly or as an ingredient of compound medicines, in Sri Lanka to cure several diseases as given in table below.

Table 1: Medicinal uses of weeds

\begin{tabular}{|c|c|c|c|c|}
\hline $\begin{array}{c}\text { Botanical name } \\
\text { And Family }\end{array}$ & $\begin{array}{c}\text { Sinhala } \\
\text { name }\end{array}$ & English name & $\begin{array}{l}\text { Part used Indication } \\
\text { in medicine }\end{array}$ & Prescription \\
\hline $\begin{array}{l}\text { Abutilon indicum } \\
\text { (Malvaceae) }\end{array}$ & $\begin{array}{l}\text { Beheth } \\
\text { Anoda }\end{array}$ & $\begin{array}{l}\text { Indian abutilon, } \\
\text { Indian mallow }\end{array}$ & Haemorroids & $\begin{array}{l}480 \mathrm{~g} \text { of fresh leaves of } A \text {. indicum boiled well in } \\
7680 \mathrm{ml} \text { till it turns to } 1920 \mathrm{ml} \text {. The patients suffer- } \\
\text { ing from haemorroids made to dip the buttocks and } \\
\text { anal area in this decoction for about half an hour } \\
\text { and it will help to reduce haemorroids. }\end{array}$ \\
\hline
\end{tabular}

\section{Acalypha indica (Euphorbiaceae) \\ Kuppameniya Indian Acalypha Entire plant Bronchial Asthma} $\begin{aligned} & \text { Achyranthes aspera Gaskaralhaba Prickly Chaff- } \\ & \text { (Amaranthaceae) }\end{aligned}$
flower
$120 \mathrm{~g}$ of leaves of $A$. indica to be pounded well. Juice is extracted by squeezing and water is added to make the final volume $120 \mathrm{ml}$. $10 \mathrm{ml}$ of this extracted juice is given to patients suffering from Bronchial Asthma.

Entire plant of A. aspera is cut into small pieces, pounded well with scraped coconut and water added. Juice is extracted by squeezing. Then, a handful of washed rice is taken; sufficient quantity of water is added and cooked so as to obtain a Chyme. Aforesaid extracted juice is added to this Chyme and heated till it boils and serve haemorroids patients for breakfast.

Aerva lanata Polpala Polpala Entire plant Dysuria, Renal60 g of dried entire plant of A. lanata is boiled in Calculi $\quad 1920 \mathrm{ml}$ of water until it is reduced to $240 \mathrm{ml}$. Given twice a day to reduce dysuria and to expel renal calculi

Alternanthera ses- Mukunu- Dwarf copperleaf Entire plant Parkinsonis- The patients with parkinsonism are adviced to use silis wenna mEye diseases $A$. sessilis in a form of vegetable .It also helps to promote vision.

(Amaranthaceae)

Aswenna

Alyce clover,

Entire plant Renal calculi

vaginalis

Buffalo clover,

$60 \mathrm{~g}$ of dried entire plant of $A$. vaginalis is boiled in $1920 \mathrm{ml}$ of water until the final volume is reduced to $240 \mathrm{ml}$. given twice a day in treatment of renal calculi.

Amaranthus spino- Katutampala Spiny amaranth, Leaves and Obesity sus Thorny amaranth. Stem

Leaves and stem of A. spinosus are prepared as a vegetable and given to reduce obesity.

(Amaranthaceae)

Amaranthus tricolorSudu tampala Joseph's coat (Amaranthaceae)

Entire plant Menorrhagia

$20 \mathrm{~g}$ of $A$. tricolor is ground into a fine paste. This paste is mixed with $120 \mathrm{ml}$ of cow's milk, $7.5 \mathrm{gm}$ of candy sugar and $10 \mathrm{ml}$ of Bee's honey and given patients suffering from menorrhagia.

Amaranthus viridis Kura tampala Pigweed Roots Oedema

(Amaranthaceae) Slender amaranth

$120 \mathrm{~g}$ of fresh roots of A. viridis are boiled in 1920 $\mathrm{ml}$ of water until reduced to $240 \mathrm{ml}$ and given twice a day to reduce oedema and also used as a diuretic.

\begin{tabular}{|c|c|c|c|c|c|}
\hline $\begin{array}{l}\text { Asteracantha } \\
\text { longifolia } \\
\text { (Acanthaceae) }\end{array}$ & Neeramulliya & Hygrophila & Roots & $\begin{array}{l}\text { Dysuria } \\
\text { Burning sensa- } \\
\text { tion in Mic- } \\
\text { turition }\end{array}$ & $\begin{array}{l}60 \mathrm{~g} \text { of dried roots of } A \text {. longifolia are boiled in } \\
-1920 \mathrm{ml} \text { of water until it is reduced to } 240 \mathrm{ml} \text { and } \\
\text { given twice a day to reduce oedema, burning sensa- } \\
\text { tion in micturition and renal calculi. }\end{array}$ \\
\hline $\begin{array}{l}\text { Bacopa monnieri } \\
\text { (Scrophulariaceae) }\end{array}$ & Lunuwila & $\begin{array}{l}\text { Thyme leaved } \\
\text { graticula }\end{array}$ & Entire plant & $\begin{array}{l}\text { Epilepsy } \\
\text { Improve mem- } \\
\text { ory power }\end{array}$ & $\begin{array}{l}\text { Entire fresh plant of } B . \text { monnieri is cut into small } \\
\text {-pieces, pounded and juice is extracted and final } \\
\text { volume is brought to } 120 \mathrm{ml} \text { by adding little water. } \\
\text { This extracted juice is given in the morning to cure } \\
\text { epilepsy and to improve memory power. }\end{array}$ \\
\hline
\end{tabular}




\begin{tabular}{|c|c|c|c|c|}
\hline $\begin{array}{c}\text { Botanical name } \\
\text { And Family }\end{array}$ & $\begin{array}{c}\text { Sinhala } \\
\text { name }\end{array}$ & $\begin{array}{c}\text { English } \\
\text { name }\end{array}$ & $\begin{array}{l}\text { Part used } \\
\text { in medicine }\end{array}$ & Indicati \\
\hline $\begin{array}{l}\text { Barleria prionitis } \\
\text { (Acanthaceae) }\end{array}$ & Katukarandu & $\begin{array}{l}\text { Baleria } \\
\text { Porcupine } \\
\text { flower }\end{array}$ & $\begin{array}{l}\text { Entire plant } \\
\text { especially } \\
\text { Roots and } \\
\text { Leaves }\end{array}$ & Fever \\
\hline & & & & Neuralgia \\
\hline $\begin{array}{l}\text { Boerhavia diffusa } \\
\text { (Nyctaginaceae) }\end{array}$ & Pitasudupala & $\begin{array}{l}\text { Red } \\
\text { spiderling }\end{array}$ & Roots & $\begin{array}{l}\text { Dysuria } \\
\text { Burning } \\
\text { sensation in } \\
\text { micturition }\end{array}$ \\
\hline $\begin{array}{l}\text { Cardiospermum } \\
\text { halicacabum } \\
\text { (Sapindaceae) }\end{array}$ & Welpenela & $\begin{array}{l}\text { Balloon } \\
\text { vine }\end{array}$ & $\begin{array}{l}\text { Entire } \\
\text { Creeper }\end{array}$ & Aphrodisia \\
\hline $\begin{array}{l}\text { Cassia } \\
\text { occidentalis } \\
\text { (Fabaceae) }\end{array}$ & Penithora & $\begin{array}{l}\text { Coffee } \\
\text { Senna }\end{array}$ & Leaves & $\begin{array}{l}\text { Worm } \\
\text { infestations }\end{array}$ \\
\hline $\begin{array}{l}\text { Cassia tora } \\
\text { (Fabaceae) }\end{array}$ & Pethithora & $\begin{array}{l}\text { Foetid Cassia, } \\
\text { Sickle Senna }\end{array}$ & Leaves & $\begin{array}{l}\text { Cough } \\
\text { dermatitis }\end{array}$ \\
\hline $\begin{array}{l}\text { Centella asiatica } \\
\text { (Apiaceae) }\end{array}$ & Gotukola & $\begin{array}{l}\text { Indian } \\
\text { Pennywort, } \\
\text { Pegaga }\end{array}$ & Entire Plant & $\begin{array}{l}\text { Increase } \\
\text { memory } \\
\text { power }\end{array}$ \\
\hline
\end{tabular}

\begin{tabular}{|c|c|c|c|c|}
\hline $\begin{array}{l}\text { Cleome viscosa } \\
\text { (Capridaceae) }\end{array}$ & Ranmanissa & $\begin{array}{l}\text { Asian spider } \\
\text { flower }\end{array}$ & Entire Plant & Headache \\
\hline $\begin{array}{l}\text { Clitoria ternatea } \\
\text { (Fabaceae) }\end{array}$ & Katarolu & $\begin{array}{l}\text { Asian } \\
\text { pigeon } \\
\text { wings }\end{array}$ & Roots & Peptic ulcer \\
\hline $\begin{array}{l}\text { Coccinia grandis } \\
\text { (Cucurbitaceae) }\end{array}$ & Kowakka & Ivy gourd & $\begin{array}{l}\text { Roots and } \\
\text { Entire } \\
\text { Creeper }\end{array}$ & $\begin{array}{l}\text { Diabetes } \\
\text { mellitus }\end{array}$ \\
\hline $\begin{array}{l}\text { Coccinia india } \\
\text { (Cucurbitaceae) }\end{array}$ & Gonkekiri & - & Seeds & $\begin{array}{l}\text { Renal } \\
\text { calculi }\end{array}$ \\
\hline $\begin{array}{l}\text { Corchorus olito- } \\
\text { rius (Tiliaceae) }\end{array}$ & Galkura & Nalta Jute & Entire plant & $\begin{array}{l}\text { Diabetes } \\
\text { mellitus }\end{array}$ \\
\hline Cyperus rotundus & Kaladuru & Nut grass & Rhizome & Diarrhoea. \\
\hline
\end{tabular}

$120 \mathrm{~g}$ of fresh leaves of Barleria prionitis are pounded
and juice is extracted by squeezing. $120 \mathrm{ml}$ of extracted

juice is given in fever.
$60 \mathrm{~g}$ of roots of $B$. prionitis are boiled in $1920 \mathrm{ml}$ of water until the final volume become $240 \mathrm{ml} .20 \mathrm{ml}$ of this decoction is given twice a day in neuralgia.

$60 \mathrm{~g}$ of roots are boiled in $1920 \mathrm{ml}$ of water until the final volume becomes $240 \mathrm{ml}$ and decoction is prepared.
This is given in dysuria, oedema and burning sensation in micturition.

Entire creeper of $C$. halicacarbum are heated on a pan with red onions and ghee till it is cooked and given as an aphrodisiac medicine ${ }^{1}$.

$120 \mathrm{~g}$ of leaves of $C$. occidentalis are boiled in $1920 \mathrm{ml}$ of water until the final volume is reduced to $240 \mathrm{ml}$ and given to patients suffering from worm infestations.

$120 \mathrm{~g}$ of leaves of $C$. tora are boiled in $1920 \mathrm{ml}$ of water until the final volume reduced to $240 \mathrm{ml}$ and given to patients suffering from cough and dermatitis.

Entire plants of $C$. asiatica are pounded with scraped coconut and juice is extracted. Handful of raw red rice is cooked with water till it turns to a thick gruel. Extracted juice is mixed with this gruel, it is called "Gotukola Kenda" and given to drink daily to improve memory power.

Leaves and pods of $C$. viscosa are ground together into a fine paste and applied over forehead to reduce headache.

Roots of $C$. ternatea are pounded into a fine paste and given with Bee's honey and ghee to those suffering from peptic ulcer.

$120 \mathrm{~g}$ of fresh entire creeper of $C$. grandis is boiled in $1920 \mathrm{ml}$ of water until reduced to $240 \mathrm{ml}$ and given to control diabetes mellitus.

$3 \mathrm{~g}$ of powdered seeds of $C$. india are given with 1.25 gm of rock salt daily to treat renal calculi.

Entire plant of $C$. olitorius is ground with Bee's honey and $10 \mathrm{gm}$ given twice a day to treat diabetes patients.

(Cyperaceae)

$60 \mathrm{~g}$ of dried rhizome of C. rotundus is boiled in 1920 $\mathrm{ml}$ of water until reduced to $240 \mathrm{ml}$ and given to control diarrhoea.

Eclipta prostrata Keekirindiya False Daisy Entire plant Gastritis

Equal parts of entire plant of E. prostrate and pericarp of Terminalia chebula are taken and powdered well.10 $\mathrm{g}$ of this powder is given twice a day with jaggery to patients suffering from gastritis.

Elephantopus sca- Ethadi

ber

Elephant's Foot

(Asteraceae)

Eleusine indica

Balathana

(Poaceae)

Emilia sonchifolia Kadupahara (Asteraceae)

Lilac tassel flower

Eriocaulon quin- Heen Kokquingulare mota (Eriocaulonaceae)
Fresh leaves are crushed and applied to stop bleeding from wounds. It is also used in treatment of fractures, abscess and cancers.

Roots or entire plant of E. indica are mixed with scraped coconut and a piece of Curcuma domestica. The mxiture is pounded well and heated on a pan till it is cooked. Pack over sprained muscles and bandage well.

Entire plant of E. sonchifolia is cooked and given as a vegetable to the patients suffering from fever, cough and diarrhoea.

Entire plant Liver diseases $120 \mathrm{~g}$ of entire plant of E. quinquingulare is boiled in Jaundice $\quad 1920 \mathrm{ml}$ of water and reduceed to $240 \mathrm{ml}$.Given twice a Splenomegaly day to treat patients suffering from Liver disorders, Jaundice and splenomegaly. 


\begin{tabular}{|c|c|c|c|c|c|}
\hline $\begin{array}{l}\text { Botanical name } \\
\text { and Family }\end{array}$ & $\begin{array}{c}\text { Sinhala } \\
\text { name }\end{array}$ & $\begin{array}{l}\text { English } \\
\text { name }\end{array}$ & $\begin{array}{l}\text { Part used } \\
\text { in medicine }\end{array}$ & Indication & Prescription \\
\hline $\begin{array}{l}\text { Euphorbia hirta } \\
\text { (Euphorbiaceae) }\end{array}$ & $\begin{array}{l}\text { Bu- } \\
\text { dadakeeriya }\end{array}$ & Asthma weed & Roots & Renal calculi & $\begin{array}{l}120 \mathrm{~g} \text { of fresh entire plant of E. hirta is boiled in } \\
1920 \mathrm{ml} \text { of water until reduced to } 240 \mathrm{ml} \text {. This decoc- } \\
\text { tion is given twice a day to treat renal calculi. }\end{array}$ \\
\hline $\begin{array}{l}\text { Euphorbia indica } \\
\text { (Euphorbiaceae) }\end{array}$ & $\begin{array}{l}\text { Ela- } \\
\text { dadakeeriya }\end{array}$ & - & Roots & $\begin{array}{l}\text { Renal calculi } \\
\text { Dysuria } \\
\text { Bronchial } \\
\text { Asthma }\end{array}$ & $\begin{array}{l}120 \mathrm{~g} \text { of fresh entire plant of } E \text {. indica is boiled in } \\
1920 \mathrm{ml} \text { of water until reduced to } 240 \mathrm{ml} \text {. This decoc- } \\
\text { tion is given twice a day to treat renal calculi, dysuria } \\
\text { and bronchial asthma. }\end{array}$ \\
\hline $\begin{array}{l}\text { Gynandropsis } \\
\text { gynandra } \\
\text { (Capparidaceae) }\end{array}$ & Vela & $\begin{array}{l}\text { African } \\
\text { spider } \\
\text { flower }\end{array}$ & $\begin{array}{l}\text { Entire } \\
\text { plant }\end{array}$ & $\begin{array}{l}\text { Worm } \\
\text { infestation }\end{array}$ & $\begin{array}{l}5 \mathrm{~g} \text { of powdered seeds of } \mathrm{G} \text {. gynandra mixed with sugar } \\
\text { and given to treat worm infestations. }\end{array}$ \\
\hline $\begin{array}{l}\text { Heliotropium } \\
\text { indicum } \\
\text { (Boraginaceae) }\end{array}$ & Ethhoda & $\begin{array}{l}\text { Indian } \\
\text { heliotrope }\end{array}$ & $\begin{array}{l}\text { Entire } \\
\text { plant }\end{array}$ & $\begin{array}{l}\text { Dermatitis, } \\
\text { Joint } \\
\text { Swelling }\end{array}$ & $\begin{array}{l}\text { Leaves and roots are ground into fine paste and applied } \\
\text { in treatment of dermatitis and swollen joints. }\end{array}$ \\
\hline $\begin{array}{l}\text { Hemidesmum in- } \\
\text { dicus } \\
\text { (Asclepiadaceae) }\end{array}$ & Iramusu & $\begin{array}{l}\text { Indian } \\
\text { Sarsaparilla }\end{array}$ & $\begin{array}{l}\text { Entire } \\
\text { Creeper }\end{array}$ & Dermatitis & $\begin{array}{l}60 \mathrm{~g} \text { of entire creeper of } \mathrm{H} \text {. indicus is boiled in } 1920 \mathrm{ml} \\
\text { of water until reduced to } 240 \mathrm{ml} \text {. This decoction is used } \\
\text { to treat patients suffering from dermatitis. }\end{array}$ \\
\hline $\begin{array}{l}\text { Hygrophila spinosa } \\
\text { (Acanthaceae) }\end{array}$ & Ikiri & Sea Holly & Roots & $\begin{array}{l}\text { Dysuria } \\
\text { Burning } \\
\text { sensation in } \\
\text { micturition }\end{array}$ & $\begin{array}{l}60 \mathrm{~g} \text { of entire creeper of } H \text {. spinosa is boiled in } 1920 \mathrm{ml} \\
\text { of water until reduced to } 240 \mathrm{ml} \text {. This is given to pa- } \\
\text { tients suffering from dysuria and burning sensation in } \\
\text { micturition. }\end{array}$ \\
\hline $\begin{array}{l}\text { Imperata cylindrica } \\
\text { (Poaceae) }\end{array}$ & Illuk & Red Baron & Roots & $\begin{array}{l}\text { Dysuria, } \\
\text { Menorrhagia }\end{array}$ & $\begin{array}{l}60 \mathrm{~g} \text { of } \mathrm{I} \text {. cylindrical is boiled with } 1920 \mathrm{ml} \text { of water } \\
\text { till reduced to } 240 \mathrm{ml} \text {. This decoction can be given to } \\
\text { patients suffering from dysuria and menorrhagia. }\end{array}$ \\
\hline $\begin{array}{l}\text { Indigofera tinctoria } \\
\text { (Fabaceae) }\end{array}$ & Nilavariya & Indigo & Leaves & $\begin{array}{l}\text { Promote } \\
\text { Hair growth }\end{array}$ & $\begin{array}{l}\text { Leaves of } I \text {. tinctoria are pounded and juice is extracted } \\
\text { by squeezing. Oil for applying on head is prepared with } \\
\text { aforesaid juice and Sesame oil according to Thaila Prib- } \\
\text { hasha (Rules and regulations of preparing oil.) }\end{array}$ \\
\hline $\begin{array}{l}\text { Ipomoea pes- } \\
\text { tigridis } \\
\text { (Convolvulaceae) }\end{array}$ & Divi pahuru & $\begin{array}{l}\text { Tigers Foot } \\
\text { Morning } \\
\text { Glory }\end{array}$ & $\begin{array}{l}\text { Entire } \\
\text { creeper }\end{array}$ & Rabies & $\begin{array}{l}\text { Entire creeper of } I \text {. pes-tigridis is crushed well and } \\
\text { juice is extracted. This fresh juice is administered orally } \\
\text { or used in errhine therapy to cure or prevent rabies if } \\
\text { bitten by a dog suffering from rabies. }\end{array}$ \\
\hline $\begin{array}{l}\text { Jatropha glandulif- } \\
\text { era } \\
\text { (Euphorbiaceae) }\end{array}$ & Deththa & - & Root & Piles & $\begin{array}{l}\text { Roots of } J . \text { glandulifera are ground and applied over } \\
\text { haemorrhoids to reduce swelling and pain. }\end{array}$ \\
\hline $\begin{array}{l}\text { Lantana camara } \\
\text { (Verbenaceae) }\end{array}$ & Gadapana & Spanish flag & Leaves & $\begin{array}{l}\text { Joint } \\
\text { swelling }\end{array}$ & $\begin{array}{l}\text { Leaves of L. camara are pounded together with a } \\
\text { piece of rhizome of Curcuma domestica and ground } \\
\text { well, mixed with oil of Azadirachta indica and applied } \\
\text { over swollen joints. }\end{array}$ \\
\hline $\begin{array}{l}\text { Leucas zeylanica } \\
\text { (Lamiaceae) }\end{array}$ & Getathumba & $\begin{array}{l}\text { Ceylon slit- } \\
\text { wort }\end{array}$ & $\begin{array}{l}\text { Entire } \\
\text { plant }\end{array}$ & $\begin{array}{l}\text { Worm } \\
\text { infestations }\end{array}$ & $\begin{array}{l}120 \mathrm{~g} \text { of fresh } L \text {. zeylanica is boiled in } 1920 \mathrm{ml} \text { of water } \\
\text { until reduced to } 240 \mathrm{ml} .120 \mathrm{ml} \text { of decoction is given } \\
\text { twice a day to worm infestations. }\end{array}$ \\
\hline $\begin{array}{l}\text { Mimosa pudica } \\
\text { (Fabaceae) }\end{array}$ & $\begin{array}{l}\text { Heen Nidi- } \\
\text { kumba }\end{array}$ & $\begin{array}{l}\text { Sensitive } \\
\text { plant }\end{array}$ & $\begin{array}{l}\text { Entire } \\
\text { plant }\end{array}$ & Dermatitis & $\begin{array}{l}\text { Entire plant of } M \text {. pudica is boiled with leaves of } \\
\text { Azadirachta indica and pieces of rhizome of Curcuma } \\
\text { domestica. This is used to wash and Clean the patients } \\
\text { suffering from dermatitis. }\end{array}$ \\
\hline $\begin{array}{l}\text { Ocimum sanctum } \\
\text { (Lamiaceae) }\end{array}$ & Maduruthala & Holy Basil & $\begin{array}{l}\text { Entire } \\
\text { plant }\end{array}$ & Fever & $\begin{array}{l}60 \mathrm{~g} \text { of entire plant of } O \text {. sanctum is boiled in } 1920 \mathrm{ml} \\
\text { water until final volume becomes } 240 \mathrm{ml} .120 \mathrm{ml} \text { of } \\
\text { this decoction is mixed with dried powder of ginger and } \\
\text { given to patients suffering fever including malaria. }\end{array}$ \\
\hline $\begin{array}{l}\text { Oldenlandia corym- } \\
\text { bosa } \\
\text { (Rubiaceae) }\end{array}$ & $\begin{array}{l}\text { - Walpatpada- } \\
\text { gam }\end{array}$ & $\begin{array}{l}\text { Flat-Top Mille } \\
\text { Graines }\end{array}$ & $\begin{array}{l}\text { entire } \\
\text { plant }\end{array}$ & $\begin{array}{l}\text { Renal } \\
\text { disorders }\end{array}$ & $\begin{array}{l}\text { Entire plant of } O \text {. corymbosa is boiled in water as to } \\
\text { make a herbal tea or decoctions are prepared and given } \\
\text { to patients suffering from various renal disorders. }\end{array}$ \\
\hline $\begin{array}{l}\text { Oxalis corniculata } \\
\text { (Oxalidaceae) }\end{array}$ & $\begin{array}{l}\text { Embulam- } \\
\text { biliya }\end{array}$ & $\begin{array}{l}\text { Creeping } \\
\text { woodsorrel }\end{array}$ & $\begin{array}{l}\text { Entire } \\
\text { plant }\end{array}$ & Anorexia & $\begin{array}{l}120 \mathrm{~g} \text { of entire plant of } O \text {. corniculata are pounded a } \\
\text { little amount of water is added and juice is extracted by } \\
\text { squeezing } 30 \mathrm{ml} \text { of juice given twice a day to reduce } \\
\text { anorexia. }\end{array}$ \\
\hline
\end{tabular}




\begin{tabular}{|c|c|c|c|c|c|}
\hline $\begin{array}{l}\text { Botanical name } \\
\text { and Family }\end{array}$ & $\begin{array}{l}\text { Sinhala } \\
\text { name }\end{array}$ & English name & $\begin{array}{l}\text { Part used } \\
\text { in medicine }\end{array}$ & Indication & Prescription \\
\hline $\begin{array}{l}\text { Peperomia pellu- } \\
\text { cida } \\
\text { (Piperaceae) }\end{array}$ & $\begin{array}{l}\text { Wathura } \\
\text { Gas }\end{array}$ & $\begin{array}{l}\text { Pepper elder } \\
\text { Peperomia }\end{array}$ & Entire plant & Burns & $\begin{array}{l}\text { Entire plant of } P \text {. pellucida is crushed and rubbed } \\
\text { over the burned area to reduce burning sensation } \\
\text { and prevent blisters due to burns. }\end{array}$ \\
\hline $\begin{array}{l}\text { Phyllanthus debilis } \\
\text { (Euphorbiaceae) }\end{array}$ & Pitawakka & Niruri & Entire plant & Sinusitis & $\begin{array}{l}120 \mathrm{~g} \text { of fresh plant } P \text {. debilis is boiled in } 1920 \mathrm{ml} \\
\text { of water until reduced to } 240 \mathrm{ml} .120 \mathrm{ml} \text { of decoc- } \\
\text { tion is given twice a day in sinusitis. }\end{array}$ \\
\hline $\begin{array}{l}\text { Phyllanthus uri- } \\
\text { naria } \\
\text { (Euphorbiaceae) }\end{array}$ & Rathpitawakke & aChamber bitter & Entire plant & Sinusitis & $\begin{array}{l}120 \mathrm{~g} \text { of fresh entire plant of } P \text {. urinaria is boiled in } \\
1920 \mathrm{ml} \text { of water until reduced to } 240 \mathrm{ml} .120 \mathrm{ml} \text { of } \\
\text { decoction is given twice a day in sinusitis. }\end{array}$ \\
\hline $\begin{array}{l}\text { Polygonum barba- } \\
\text { tum (Polygonaceae) }\end{array}$ & Kimbulwenna & $\begin{array}{l}\text { Joint weed, } \\
\text { Knotgrass }\end{array}$ & Entire plant & Diarrhoea & $\begin{array}{l}\text { Entire plant of } P \text {. herbatum is boiled in water and } \\
\text { used to treat patients suffering from diarrhoea. }\end{array}$ \\
\hline $\begin{array}{l}\text { Portulaca oleracea } \\
\text { (Portulaceae) }\end{array}$ & Genda Kola & little hogweed & $\begin{array}{l}\text { Entire } \\
\text { plant }\end{array}$ & $\begin{array}{l}\text { Haematuria } \\
\text { Dysuria, Piles } \\
\text { Dermatitis }\end{array}$ & $\begin{array}{l}\text { Entire plant of } P \text {. oleraceae is cooked and used as a } \\
\text { vegetable by patients suffering from haematuria } \\
\text { dysuria, piles and dermatitis. }\end{array}$ \\
\hline $\begin{array}{l}\text { Psidium guajava } \\
\text { (Myrtaceae) }\end{array}$ & Pera & Guava & Leaves & $\begin{array}{l}\text { Pityriasis } \\
\text { versicolor }\end{array}$ & $\begin{array}{l}\text { Leaves of } P \text {. gujava are crushed and rubbed on the } \\
\text { areas infected to reduce pityriasis versicolor. }\end{array}$ \\
\hline $\begin{array}{l}\text { Scoparia dulcis } \\
\text { (Scrophulariaceae) }\end{array}$ & Walkottamalli & Sweet Broom & $\begin{array}{l}\text { Entire } \\
\text { plant }\end{array}$ & $\begin{array}{l}\text { Diabetes } \\
\text { mellitus } \\
\text { Renal calculi } \\
\text { Diarrhoea }\end{array}$ & $\begin{array}{l}120 \mathrm{~g} \text { of fresh } \text { S.dulcis is boiled in } 1920 \mathrm{ml} \text { of water } \\
\text { until reduced to } 240 \mathrm{ml} \text { and given twice a day to } \\
\text { control Diabetes mellitus and to expel renal calculi. }\end{array}$ \\
\hline $\begin{array}{l}\text { Sida acuta } \\
\text { (Malvaceae) }\end{array}$ & Gas Bebila & $\begin{array}{l}\text { Common wire } \\
\text { weed }\end{array}$ & Roots & Neuralgia & $\begin{array}{l}60 \mathrm{~g} \text { of dried roots of } S . \text { acuta are boiled in } 1920 \mathrm{ml} \\
\text { of water until reduced to } 240 \mathrm{ml} \text { and given twice a } \\
\text { day to reduce pain especially in neuralgia. }\end{array}$ \\
\hline $\begin{array}{l}\text { Sida cordifolia } \\
\text { (Malvaceae) }\end{array}$ & Wal-bebila & Country mallow & $\begin{array}{l}\text { Leaves } \\
\text { Roots }\end{array}$ & Insanity & $\begin{array}{l}\text { Leaves of } S \text {. cordifolia boiled with cow's milk and } \\
\text { ground into a fine paste and mixed with Sesame oil } \\
\text { This is applied over scalp and kept about half an } \\
\text { hour to treat insanity. }\end{array}$ \\
\hline $\begin{array}{l}\text { Sida rhombifolia } \\
\text { (Malvaceae) }\end{array}$ & $\begin{array}{l}\text { Kotikan Be- } \\
\text { bila }\end{array}$ & Cuban jute & Roots & Fever & $\begin{array}{l}60 \mathrm{~g} \text { of dried roots of } S \text {. rhombifolia are boiled in } \\
1920 \mathrm{ml} \text { of water until reduced to } 240 \mathrm{ml} \text { and } \\
\text { given twice a day to reduce fever. }\end{array}$ \\
\hline $\begin{array}{l}\text { Solanum nigrum } \\
\text { (Solanaceae) }\end{array}$ & $\begin{array}{l}\text { Kalukam- } \\
\text { meriya }\end{array}$ & $\begin{array}{l}\text { Black } \\
\text { Nightshade }\end{array}$ & $\begin{array}{l}\text { Entire } \\
\text { plant }\end{array}$ & Erysipelas & $\begin{array}{l}\text { Leaves of } S \text {. americanum are ground with ghee and } \\
\text { applied on lesions. }\end{array}$ \\
\hline $\begin{array}{l}\text { Sphaeranthus in- } \\
\text { dicus } \\
\text { (Asteraceae) }\end{array}$ & Mudumahana & $\begin{array}{l}\text { East Indian } \\
\text { Globe Thistle }\end{array}$ & $\begin{array}{l}\text { Entire } \\
\text { plant }\end{array}$ & $\begin{array}{l}\text { Chronic cough } \\
\text { Rhinitis }\end{array}$ & $\begin{array}{l}\text { Entire plant of } S \text {. indicus is powdered and } 2.5 \mathrm{~g} \text { of } \\
\text { this powder is given to treat chronic cough and } \\
\text { rhinitis. }\end{array}$ \\
\hline $\begin{array}{l}\text { Sphenoclea zey- } \\
\text { lanica } \\
\text { (Sphenocleaceae) }\end{array}$ & $\begin{array}{l}\text { Mahamudu- } \\
\text { mahana }\end{array}$ & Chick & $\begin{array}{l}\text { Entire } \\
\text { plant }\end{array}$ & $\begin{array}{l}\text { Enhance the } \\
\text { growth of hair }\end{array}$ & $\begin{array}{l}\text { Oil is prepared from entire plant of } S \text {. zeylanica and } \\
\text { Sesame oil according to Thaila Parbhasha. }\end{array}$ \\
\hline $\begin{array}{l}\text { Spilanthes calva } \\
\text { (Asteraceae) }\end{array}$ & Akmella & $\begin{array}{l}\text { Toothache } \\
\text { plant }\end{array}$ & $\begin{array}{l}\text { Leaves } \\
\text { Roots }\end{array}$ & Toot & $\begin{array}{l}\text { Leaves are crushed and kept over dental caries to } \\
\text { reduce the pain. }\end{array}$ \\
\hline $\begin{array}{l}\text { Tephrosia purpurea } \\
\text { (Fabaceae) }\end{array}$ & Kathurupila & Wild Indigo & Roots & $\begin{array}{l}\text { Jaundice } \\
\text { Splenomegaly }\end{array}$ & $\begin{array}{l}\text { Roots of } T \text {. purpura are burned in an earthen pot till } \\
\text { it turns to ash. } 1-2 \mathrm{~g} \text { of ash is given to treat jaundice } \\
\text { and splenomegaly. }\end{array}$ \\
\hline $\begin{array}{l}\text { Trianthema portula- } \\
\text { castrum } \\
\text { (Aizoaceae) }\end{array}$ & -Sarana & $\begin{array}{l}\text { Desert } \\
\text { Horse-Purslane }\end{array}$ & Roots & $\begin{array}{l}\text { Dysuria Oe- } \\
\text { dema }\end{array}$ & $\begin{array}{l}60 \mathrm{~g} \text { of roots of } T \text {. portulacastrum are boiled in } \\
1920 \mathrm{ml} \text { of water until reduced to } 240 \mathrm{ml} \text { and given } \\
\text { twice a day in treatment of dysuria and oedema. }\end{array}$ \\
\hline $\begin{array}{l}\text { Tribulus terrestris } \\
\text { (Zigophyllaceae) }\end{array}$ & Heen Gokatu & $\begin{array}{l}\text { Goathead } \\
\text { Puncture vine }\end{array}$ & $\begin{array}{l}\text { Entire } \\
\text { plant }\end{array}$ & $\begin{array}{l}\text { Dysuria } \\
\text { Renal calculi }\end{array}$ & $\begin{array}{l}60 \mathrm{~g} \text { of entire plant of } T \text {. terrestris is boiled in } 1920 \\
\mathrm{ml} \text { of water until reduced to } 240 \mathrm{ml} \text { and given twice } \\
\text { a day in treatment of dysuria and renal calculi. }\end{array}$ \\
\hline $\begin{array}{l}\text { Vernonia } \\
\text { anthelmintica } \\
\text { (Asteraceae) }\end{array}$ & Sanninayam & $\begin{array}{l}\text { Ironweed, Purple } \\
\text { fleabane }\end{array}$ & Seeds & Leucoderma & $\begin{array}{l}\text { Oil is prepared with seeds of } V \text {. antihelmintica and } \\
\text { Sesame oil according to Thaila Paribhasha and } \\
\text { applied on leucoderma patches. This oil helps to } \\
\text { turn the leucoderma patches into brown colour. }\end{array}$ \\
\hline $\begin{array}{l}\text { Vernonia cinerea } \\
\text { (Asteraceae) }\end{array}$ & $\begin{array}{l}\text { Monara- } \\
\text { kudumbiya }\end{array}$ & $\begin{array}{l}\text { Lttle ironweed } \\
\text { Purple fleabane }\end{array}$ & Entire plant & Jaundice & $\begin{array}{l}\text { Handful of entire plant of } V \text {. cinera is cut into small } \\
\text { pieces and pounded. Water is added and the juice is }\end{array}$ \\
\hline
\end{tabular}




\begin{tabular}{|c|c|c|c|c|c|}
\hline $\begin{array}{c}\text { Botanical name } \\
\text { and Family }\end{array}$ & $\begin{array}{c}\text { Sinhala } \\
\text { name }\end{array}$ & English name & $\begin{array}{c}\text { Part used } \\
\text { in medicine }\end{array}$ & $e^{\text {Indication }}$ & Prescription \\
\hline & & & & & $\begin{array}{l}\text { extracted by squeezing. Handful of red rice mixed } \\
\text { with water and boiled till is turns to a thick gruel. } \\
\text { Aforesaid juice is mixed with gruel, boiled and given } \\
\text { to patients suffering from jaundice. }\end{array}$ \\
\hline $\begin{array}{l}\text { Withania somnif- } \\
\text { era } \\
\text { (Solanaceae) }\end{array}$ & Amukkara & $\begin{array}{l}\text { Indian Ginseng } \\
\text { Winter Cherry }\end{array}$ & Roots & $\begin{array}{l}\text { Impotency } \\
\text { Infertility }\end{array}$ & $\begin{array}{l}\text { Roots of } W \text {. somnifera are powdered. } 5-10 \mathrm{~g} \text { of this } \\
\text { powder is fried with sufficient quantity of ghee and } \\
\text { given to drink with cow's milk to treat impotency } \\
\text { and infertility. }\end{array}$ \\
\hline
\end{tabular}

\section{DISCUSSION}

Almost sixty five plants which are considered as weeds, are used as medicines by Ayurvedic and Traditional physicians in Sri Lanka. These plants belong to thirty five families. Entire plant or different parts of the plants such as roots, root bark, stem, stem bark, flowers, leaves, fruits and seeds are used as medicine. They are used in treatment of various diseases such as worm infestations, dysuria, polyurea, renal calculi, neuralgia, wounds, jaundice, impotency, diarrhoea, dermatitis, sinusitis, haemorrhoids, muscle sprains, pyrexia, spleen and liver disorders. Some weeds such as A. lanata, A. sessilis, A. viridis, A. longifolia, $C$. asiatica, C. halicacarbum, C. occidentalis, C. tora, $C$. grandis, L. zeylanica, O. corniculata, P. oleraceae, $S$. indicus, $T$. portulacastrum, A. viridis and $V$. cinera are edible and are used as vegetables, used in preparing herbal chymes and herbal teas.

\section{SUMMARY AND CONCLUSION}

The focus of an agriculturist would be on the main cash crop that is being grown in an agricultural land. Therefore, he would generally consider other plants that spring up in this area without any known benefit to the farmer, as an obstacle. Therefore, agriculturists and weediologist should pay special attention to identify beneficial weeds. They should take care to promote beneficial weeds and to preserve and propagate them, which are medicinally valuable. It is concluded that weeds are valuable medicines and should be protected. The world must be made aware of the medicinal values of weeds. This will help the availability of medicinal plants in abundance and promote Ayurvedic and Traditional medicine while financially benefiting the farmer too.

\section{REFERENCE}

Knanawimala, K. (1970) Deshiya Vaidya Shad ha Kosha, Shasthrodaya Mudranalaya, Ratnapura, Sri Lanka. P2, 117, 262, 342, 472

Anonymous (1985) Ayurveda Pharmacopeia, Department of Ayurveda, Colombo, Sri Lanka, Volume 1 Part 11: 42, 151

Anonymous (1979) Ayurveda Pharmacopeia, Department of Ayurveda, Colombo, Sri Lanka, Volume 1 Part 111: 42

Anonymous (1994) Osu Visithuru, Department of Ayurveda, Colombo, Sri Lanka, Volume 1: 29, 33, 100, 121, 183, 242, 267

Anonymous (1994) Osu Visithuru, Department of Ayurveda, Colombo, Sri Lanka, Volume 11:28, 60, 170, 186, 257, 264

Anonymous (1994) Osu Visithuru, Department of Ayurveda, Colombo, Sri Lanka, Volume $111: 237,55,65,81$

Anonymous (1994) Osu Visithuru, Department of Ayurveda, Colombo, Sri Lanka, Volume 1V : 123, 256, 323

Ediriweera, E.R.H.S.S. and Ratnasooriya, W. D. (2002) Antidiuretic effect of Scoparia dulcis in rats J.Trop. Med. Plants. 3: 55-58

Ratnasooriya, W.D., Galhena G., Liyanage S.S.P., Jayakody J.R.A.C., Hettiarchchi H.D.I. and Ediriweera, E. R.H.S.S. (2003) Analgesic and antihyperalgesic activities of decoction of Sri Lankan Scoparia dulcis. J.Trop. Med. Plants 4 : 63-70

Ratnasooriya, W.D., Jayakody, J.R.A.C., Premakumara, G.A.S. and Ediriweera E.R.H. S.S. (2005) Antioxident activity of water extract of Scoparia dulcis Fitotherpia.76: 220-222

Ratnasooriya, W.D., Galhena G., Liyanage S.S.P., Jayakody J.R.A.C., Hettiarchchi H.D.I. and Ediriweera, E.R.H.S.S. (2005) Antidiarrhoeal activity of decoction of Scoparia dulcis in rats. Vidyodaya J. Sc 12:57-64 